\title{
Victims of "adaptation": climate change, sacred mountains, and perverse resilience
}

\author{
Adam Dunstan ${ }^{1}$ \\ University of North Texas, USA
}

\begin{abstract}
Resiliency and adaptation are increasingly prevalent in climate change policy as well as scholarship, yet scholars have brought forward several critiques of these concepts along analytical as well as political lines. Pressing questions include: who resiliency is for, what it takes to maintain it, and the scale at which it takes place. The concept of "perverse resilience", for example, proposes that resiliency for one sub-system may threaten the well-being of the overall system. In this article, I propose the related concept of "perverse adaptation", where one actor or institution's adaptation to climate change in fact produces aftershocks and secondary impacts upon other groups. Drawing on ethnographic and sociolinguistic research in northern Arizona regarding artificial snowmaking at a ski resort on a sacred mountain, I elucidate resort supporters' and others' attempts to frame snowmaking as a sustainable adaptation to drought (and, implicitly, climate change). I counterpoise these framings with narratives from local activists as well as Diné (Navajo) individuals regarding the significant impacts of snowmaking on water supply and quality, sacred lands and ceremony, public health, and, ironically, carbon emissions. In so doing, I argue that we must interrogate resilience policies for their unexpected "victims of adaptation."
\end{abstract}

Key words: climate change policy, adaptation, perverse resilience, sacred sites, Diné (Navajo)

\section{Résumé}

La résilience et l'adaptation sont de plus en plus répandues dans la politique sur le changement climatique et dans les études sur ces questions, mais les universitaires ont avancé plusieurs critiques de ces concepts selon des lignes analytiques et politiques. Les questions pressantes comprennent: à qui s'adresse la résilience, ce qu'il faut pour la maintenir et l'échelle à laquelle elle se déroule. Le concept de «résilience perverse», par exemple, propose que la résilience pour un sous-système puisse menacer le bien-être du système global. Dans cet article, je propose le concept $d$ '«adaptation perverse», où l'adaptation d'un acteur ou d'une institution au changement climatique produit en fait des répliques et des impacts secondaires sur d'autres groupes. En m'appuyant sur des recherches ethnographiques et sociolinguistiques dans le nord de l'Arizona concernant l'enneigement artificiel dans une station de ski sur une montagne sacrée, j'explique les tentatives des partisans de la station et d'autres pour concevoir l'enneigement comme une adaptation durable à la sécheresse (et, implicitement, au changement climatique). Je contrebalance ces cadrages avec des récits d'activistes locaux ainsi que de personnes Diné (Navajo) concernant les impacts importants de l'enneigement sur la qualité et l'approvisionnement en eau, les terres sacrées et les cérémonies, la santé publique et, ironiquement, les émissions de carbone. Ce faisant, je soutiens que nous devons interroger les politiques de résilience pour leurs "victimes d'adaptation" inattendues. Mots-clés: politique du changement climatique, adaptation, résilience perverse, sites sacrés, Diné (Navajo)

\footnotetext{
${ }^{1}$ Dr. Adam Dunstan, Assistant Professor of Anthropology, University of North Texas, USA. Email: adam.dunstan "at" unt.edu. I would like to express my deep gratitude to the individuals who were interviewed during the course of this research and who shared their knowledge with me, especially grassroots anti-snowmaking volunteers. Thank you as well to the anonymous reviewer for very helpful comments, to my co-researcher Charleen, as well as Dr. Casey Walsh and the other editors at Journal of Political Ecology. Portions of this research were funded by the Jacobs Research Funds, the Charles Redd Center for Western Studies, the David M. Kennedy Center for International Studies, the Mark Diamond Research Fund, and the McNulty Grant for Cultural Studies.
} 


\section{Resumen}

Resiliencia y adaptación se han vuelto cada vez más comunes tanto en política sobre cambio climático como en su estudio. Sin embargo, académicos han formulado diversas críticas de estos conceptos con argumentos tanto analíticos como políticos. Entre las cuestiones más apremiantes están: para quién es la resiliencia, qué se requiere para mantenerla, y la escala en la que se presenta. El concepto de "resiliencia perversa", por ejemplo, propone que la resiliencia para un subsistema puede amenazar el bienestar del sistema completo. En este artículo propongo el concepto relacionado de "adaptación perversa", donde la adaptación de un actor o institución al cambio climático produce, de hecho, réplicas e impactos secundarios sobre otros grupos. Con base en trabajo etnográfico y sociolingüístico sobre la producción artificial de nieve en un centro de esquí, en una montaña sagrada en el norte de Arizona, ilustro los intentos por parte de los partidarios del centro, así como de otros actores, por plantear la fabricación de nieve como adaptación sustentable a la sequía (e implícitamente, al cambio climático). Luego, pongo en contrapeso estos planteamientos con las narrativas de activistas locales, así como de individuos Diné (Navajos), con respecto a los fuertes impactos de la fabricación de nieve sobre el suministro y calidad del agua, las tierras sagradas y ceremoniales, salud pública y, de manera irónica, las emisiones de carbono. De este modo, discuto que debemos interrogar las políticas de resiliencia por sus inesperadas "víctimas de la adaptación".

Palabras clave: política en materia de cambio climático, adaptación, resiliencia perversa, sitios sagrados, Diné (Navajo)

\section{Introduction}

In Diné (Navajo) wedding baskets, a tan line transverses the curvilinear pattern of red and black. It is typically quite thin and, in some cases, almost imperceptible. The line, an intentional interruption, has a variety of teachings related to its symbolic meanings and place within the overall pattern (McPherson 2012: 146-149). Although strictly speaking the line is structurally dispensable - one could conceivably construct a basket without it - one could say that Diné wedding baskets, as a recognizable assemblage, would be impossible without this line. I open this article with an explanation of Diné wedding baskets to introduce this ethnographic case study of snowmaking and the sacred, climate and conflict because, like the circle-breaking line, climate change is a thread running through the entire narrative, sometimes bold, sometimes subtle, yet always indispensable.

The San Francisco Peaks (as they are known in English) are a cluster of peaks in northern Arizona (USA) recognized as a sacred mountain by 13 indigenous nations. The Peaks have been the site of decades of contention over land use, most recently over the expansion of a private ski resort (the Arizona Snowbowl) on public land. Much of the mountain is contained within the Coconino National Forest, and thus falls under the jurisdiction of the U.S. Forest Service (USFS). The USFS, in turn, permits Snowbowl to utilize a portion of the slopes as a ski resort. Snowbowl has recently expanded operations and commenced artificial snowmaking, despite more than a decade of litigation and grassroots opposition. This conflict revolves around a number of issues, including sacred land desecration, religious freedom, environmental health, public land uses, framing of Native Americans, and critiques of state-corporate collusion, themes addressed by myself as well as other scholars (Boggs 2017; Dunstan 2016, 2017; Glowacka et al. 2009; Richland 2017; Sefiha and Lauderdale 2008; Tsosie 2006). However, in the course of ethnographic and sociolinguistic research in northern Arizona since 2009, it has become increasingly clear to me that the snowmaking conflict is also a conflict about climate change and the proper adaptation to it.

The changing, drought-pervasive climate of Arizona is not only the backdrop but also a main character in the drama of Snowbowl, exerting pressures, prompting reactions, and generating new interpretive spaces within which the snowmaking/desecration assemblage is produced and sustained. Snowmaking as a threat, a call to action, and a cultural assault, is impossible to entirely consider without climate change as a context. Specifically, climate change has provided an ostensible justification for Snowbowl's snowmaking that is then facilitated through the City of Flagstaff's sale of reclaimed municipal wastewater that has been treated to meet specific water quality criteria and permitted by federal and state governmental agencies (U.S. Environmental 
Protection Agency 2012). Yet this very act of "adapting" to climate change through snowmaking with wastewater produces significant, and in some cases catastrophic, social and environmental impacts voiced by opponents, many of whom see this as the precise opposite of adapting to the environment. I will argue that the considerable public infrastructure and investment bent towards maintaining a drought-beleaguered ski resort is an example of what has been called "perverse resilience" (Phelan et al. 2013), or perhaps we might say "perverse adaptation." It is an illustration of how the secondary effects of climate adaptation policy - specifically by corporate actors seeking to maintain or even improve the status quo via adaptation - can leave new victims and socio-ecological havoc in its wake.

\section{Perverse resilience}

Within governmental approaches to climate change, policies explicitly focused on adaptation and resiliency are increasingly prevalent. In this article I treat resiliency and adaptation as terms which, while certainly not synonymous, are fundamentally linked within climate change policy and scholarship. Often used interchangeably within policy settings, the concepts also have a clear analytical linkage within scholarship, wherein adaptation is typically treated as a component of, and intrinsic to, resiliency. Mirroring the classic definition given by Holling (1973), resilience, both in ecology and ecologically-oriented social sciences, has broadly speaking been treated as the ability of systems to "absorb or recover from exposure to stresses", (Lazrus 2012; see also Adger et al. 2005 and Roncoli 2006). Adaptation is commonly seen as intrinsic to this ability, with resilience being "a function of...systems' adaptive capacity" (Crate 2008: 571; see also Kokorsch 2018 and Thorén and Olsson 2018: 112). There is, of course, a complex relationship here between maintenance of structure and change; in this regard I follow Hirsch in thinking of resilience as "the negotiated compromise between adaptation and resistance to fundamental change", (2017: 463, emphasis added).

After two decades of relative political neglect in favor of mitigation, adaptation is now widely viewed as integral to climate policy (Pielke et al. 2007). As noted by Adger et al. (2009), "In a new, deliberative and self-conscious way... adaptation to climate change has now become part of the contemporary discourse about the politics and economics of global climate change." The European Union saw a 635\% increase in climate adaptation policies from 2005-2010 (Massey et al. 2014) and, in 2013, the EU adopted the European Union Adaptation Strategy, which has the overt goal of helping Europe to become "climate-resilient", (European Commission n.d.). Adaptation is likewise emphasized in the United States' 2016 Climate Action Report, which stresses "working with communities and state, tribal, and local governments to build resilience and adapt to climate-related hazards" (U.S. Department of State 2016). Crate (2008: 571) remarks "Adaptation has been widely discussed in boardrooms, living rooms, and government offices, often as a substitute for mitigation of the human-induced effects of global climate change." This pervasive policy shift towards adaptation and resiliency likely reflects, at least in part, the widespread recognition that some impacts of climate change are not only unavoidable but indeed are already occurring, mitigation efforts notwithstanding.

In addition to their salience in governance, climate resiliency and adaptation have likewise generated a robust body of scholarship, an "explosion of theoretical and applied work" (McDonald 2017: 33). Resiliency now represents a dominant concept within scholarship on socio-ecological systems (Kokorsch 2018: 2). A significant portion of climate scholarship within the social sciences utilizes a resiliency paradigm and focuses on adaptive capacity (Crate 2008), as for example in the literature on urban resilience (Leichenko 2011; Newman, Beatley, and Boyer 2009), anticipatory climate-oriented learning (Tschakert and Dietrich 2010), and economic development (Cannon and Muller-Mahn 2010), among many others. In sum, the normative concept of adapting to climate change now occupies a predominant role within climate scholarship and policy discourses (Tschakert and Dietrich 2010).

Yet, at the same time, many scholars have critiqued the resiliency framework and its limitations, in general (e.g. Nadasdy 2007; Olsson et al. 2015) and specifically in relation to climate change (Crate 2008). Some have argued that an over-emphasis on adaptation may occlude the irreversible impacts of climate change and the "complexity and constraints of adaptation" as well as associated unequal impacts (Nelson et al. 2009). This "emerging discourse of limits to adaptation", to use Adger et al.'s phrase (2009: 335), emphasizes that for 
a variety of reasons (particularly sociocultural factors) adaptation to climate change cannot always be assumed to be likely or even feasible. In this vein, Crate remarks,

Although many of us are versed in the frames of adaptive capacity and resilience, we have begun to doubt that such coping mechanisms are sufficient to deal with the effects of global climate change. We realize that environmental and cultural change far beyond the reach of restoration is occurring. (2008: 569)

This article engages with a different critique of resilience, what Olsson et al. (2015) term the "politics of resilience." This diverse body of scholarship centers on the power dynamics behind adaptation-oriented policies as sociopolitical processes. Such policies do not occur in a power vacuum; adaptation is structured (and resisted) within political economies and discourses which are often hierarchical in terms of economic capital, power (Tschakert and Dietrich 2010), and ideology. This article is an attempt to engage in a "political ecology of adaptation", (Roncoli 2006: 83) by uncovering the inequalities which both produce and are produced by the "adaptation" of corporate snowmaking on a mountain that is sacred, and (under US law) public land. I place quotation marks around adaptation in part to indicate that whether this is adaptation at all is contestable (and contested) by those on the ground. In fact, an alternative perspective would be that this is a clear instance of maladaptation as defined by the Intergovernmental Panel on Climate Change (IPCC): "Actions that may lead to increased risk of adverse climate-related outcomes, including increased GHG emissions, increased vulnerability to climate change, or diminished welfare, now or in the future" (IPCC 2019: 553).

Elucidating the politics of climate adaptation involves in part interrogating the basic goals of adaptation. The ways in which individuals and communities "experience and theorize resilience... is a political act" (Hirsch 2017: 463). In this vein, Olsson et al. (2015) suggest that we ask "specific questions on resilience 'of what' and resilience 'for whom", particularly important questions in light of the significant resources mobilized in the name of adaptation. Throughout this article, I seek to foreground such questions, by analyzing framing for, and against, adaptation efforts for a ski resort and its impacts upon local environments and peoples. If resiliency is in part an effort to maintain through adaptation, I argue that in this context we must consider what the system we are attempting to maintain is, and whether it is worth maintaining at all. As Nadasdy argues in another context,

When proponents of adaptive management valorize resilience, then, they necessarily also valorize one particular set of socio-ecological relations...But why should the current equilibrium state - which is but one workable possibility - be viewed as intrinsically better than all others? Better for whom? This is a fundamentally political question. (Nadasdy 2007: 215)

For example, Thorén and Olsson (2018: 11-12) illustrate how, in regard to characterizations of Sami communities, labels of resilience may carry a political message about what is or is not necessary to be maintained for a group.

A critical aspect of the question of "resilience of what" is the issue of how resilience for one aspect of society may negatively impact others. Phelan et al. (2013), for example, describe "perverse resilience", a "resilience specific to one internal element of the overall system that is at odds with the sustainability of the system [and] can threaten overall system stability." (p. 199). They analyze the example of the fossil fuel industry remaining resilient in the face of climate change, and in so doing worsening the climate crisis affecting the entire world. In this article, I wish to adopt yet also reconfigure the "perverse resilience" heuristic to consider not only how one sub-component's adaptations can weaken an entire system, but also how the act of maintaining one aspect of society's resilience through adaptation may actively victimize and produce new burdens upon the well-being of other aspects or actors within society. In this case study, these aftershocks of adaptation include effects on the alpine forest environment, watershed sustainability, indigenous communities' sacred ecological 
relationships, carbon emissions, and public health. We might think of this type of phenomena as "perverse adaptation."

To sum up, I am considering how resilience policy, and adaptation mechanisms in particular, for one entity might harm another; how "One persons' resilience may be another person's vulnerability" (Olsson et al. 2015). This can allow us to understand what I am proposing here to be adaptation's aftershocks: the secondhand victims of climate change (via resilience policy) - victims, in other words, of adaptation (to reengineer Bodley's (1975) phrase).

To uncover these various politics of resilience, I attend to a ski resort (Arizona Snowbowl) which has enlisted federal and city support in its own purported efforts at resiliency (snowmaking) in the face of a warming climate and which has, in the process, raised significant opposition from those who see the ski resort as threatening the wellbeing of the local environment, the global climate, and indigenous peoples.

\section{Methodology}

In describing this particular case of what I am calling "perverse adaptation" my approach has been both ethnographic and sociolinguistic. In 2009, 2013, and 2014-2015, I conducted ethnographic fieldwork in northern Arizona near the San Francisco Peaks, interviewing individuals regarding Snowbowl's expansion and observing the sociopolitical context within which opposition occurs. A particular focus in my interviewing was those who actively oppose snowmaking, whom I have written about more fully elsewhere (Dunstan 2016), as well as Diné (Navajo) people living in Leupp, AZ, and other areas (Dunstan 2010, 2012). Additionally, from 2009 to 2018 I collected and analyzed examples of discourses relating to Snowbowl from, among other sources, anti-snowmaking activist media (such as websites, signs, speeches, and fliers); local and regional news media; and ski industry media.

\section{Snowmaking as "adaptation"}

The San Francisco Peaks tower above the city of Flagstaff in northern Arizona, rising to a height of 12,633 feet (3,850 meters) above sea level (Figure 1). Despite the centrality of the mountain in many indigenous sacred lifeways, it lies outside of any reservation boundaries, and is, in fact, primarily administered by the USFS as part of the Coconino National Forest. Under the auspices of the USFS, a portion of the mountain has been utilized as a private ski area (currently known as Arizona Snowbowl) since 1938 (Richland 2017; USDA Forest Service 2005). Long a subject of controversy, sustained backlash to the ski area arose in the 1970s as resort ownership sought approval for a major expansion, culminating in the first major test case of the American Indian Religious Freedom Act (Wilson v. Block), which was ultimately decided in favor of permitting expansion.

In 2002, under new ownership, the Arizona Snowbowl proposed additional expansion along with a significant change to their operations - the resort would begin artificial snowmaking using entirely reclaimed wastewater, the first U.S. ski area to do so (Richland 2017). ${ }^{2}$ USFS approved this plan in 2005 (USDA Forest Service 2005), prompting lawsuits as well as other tactics of opposition from a diverse array of actors and entities, including but certainly not limited to tribal nations, local and national environmental organizations (such as the Sierra Club - Grand Canyon Chapter), and grassroots groups specific to the snowmaking conflict (such as the Save the Peaks Coalition). A series of lawsuits against the Forest Service and City of Flagstaff ultimately upheld the expansion/snowmaking plan, most recently with a decision against the Hopi Tribe in November 2018 (Fischer 2018). Significant protests were also directed at the ski resort and various approving governmental bodies. While opponents of the expansion delayed construction for nearly a decade (2004-2011), expansion commenced in 2011. Resistance continues.

There are a variety of perspectives one can take in analyzing the Snowbowl expansion. One could consider it as a desecration of indigenous lifeways (Dunstan 2010; Glowacka et al. 2013) or utilize an

\footnotetext{
2 The initial expansion request was in fact proposed in 1996, however sans snowmaking.
} 
environmental justice framework (Lagasse 2008; see also Powell and Curley 2008: 124; Schlosberg and Carruthers 2010). It has been considered in light of rhetorical exclusion (Boggs 2017), racist discourses (Sefiha and Lauderdale 2008), as well as the legislative and jurisdictional limits of sacred site protection (Dunstan 2018; Tsosie 2006). ${ }^{3}$ All of these approaches are important dimensions of the political ecology of this conflict. I would like, in this article, to raise the additional concept of snowmaking as an aftershock of climate change. Ironically enough, while quite literally changing the (micro)climate of the San Francisco Peaks, snowmaking has at times been framed by proponents, the news media, and scholars as an adaptive response to the changing climate.

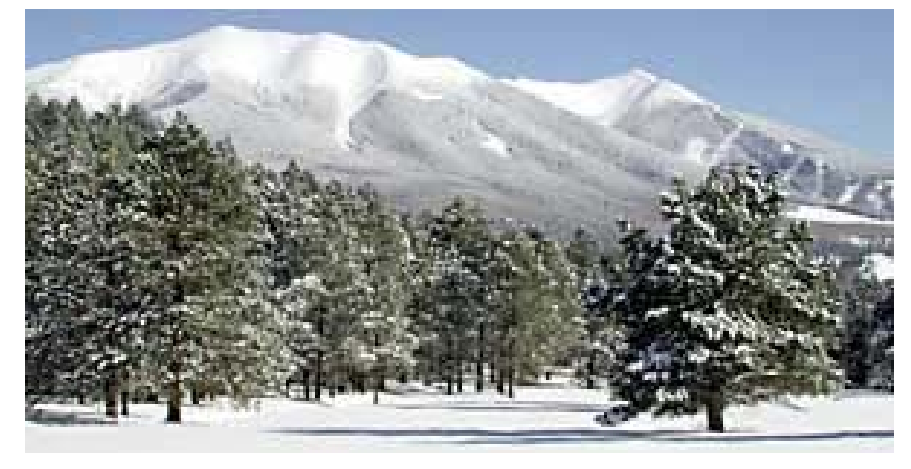

Figure 1: San Francisco Peaks and the Arizona Snowbowl. Source: Wikimedia Commons.

Climate change provides a context within which snowmaking is ostensibly justified at the San Francisco Peaks in at least two ways. The first of these is in a sense indirect, by exacerbating drought and precipitation variability. Snowmaking was primarily and originally framed as a response to interannual variability in precipitation, and to a lesser degree drought conditions, in Arizona. Thus J.R. Murray, general manager for the resort, remarked, "When the snow was great it was great, but when there was no snow it wouldn't open. We'd have ski seasons that were 20 days long and some where we got 400 inches. The difficulty is you can't plan. You can't hire and retain staff. So we needed snowmaking to stabilize things" (Long 2017, emphasis added). Similarly, Jason Stratton (a Snowbowl spokesperson) stated: "Snowmaking is a must for us to continue to exist. It gives us a future" (Konkel 2014). This is resonant with the USFS characterization of the project. The USFS stated that the primary purpose for the snowmaking/expansion is "To ensure a consistent and reliable operating season, thereby maintaining the economic viability of the Snowbowl, and stabilizing employment levels and winter tourism within the local community" (USDA Forest Service 2005). Yet such erratic interannual precipitation and droughts are neither anomalous nor static in Arizona - instead, they are what climate modeling suggest for the ski industry generally, and in particular for the Southwest under continuing climate change (Bark and Colby 2012; Chiang et al. 2018) and cannot be considered apart from this global phenomena. Thus, by exacerbating drought and precipitation chaos, climate change generates a rationale for the expansion and snowmaking at Arizona Snowbowl. One might also say it provides a pretense for growth, as another stated goal of the combined expansion/snowmaking plan is to increase capacity, as noted in the environmental impact statement (USDA Forest Service 2005).

Secondly, over time, this framing of climatological adaptation has slowly become more explicit, with snowmaking proponents and Arizona Snowbowl resort ownership overtly characterizing snowmaking as an adaptation to global climate change. For example, Snowbowl manager J.R. Murray contends that "with

\footnotetext{
${ }^{3}$ A previous article in the Journal of Political Ecology exposed the political ecology of Arizona's White Mountains, and how powerful groups exploit environmental opportunities for private gain, with "deleterious social and ecological consequences" (Collins 2008: 22).
} 
diminished snowfall due to climate change - the resort needs to supplement natural snow to maintain its season and stay in business" (paraphrased in Macmillan 2014). ${ }^{4}$ Meanwhile, USFS regional forester Corbin Newman remarks "Snow-making has become necessary because of climate change" (Macmillan 2012). Thus, snowmaking has been articulated as an attempt by the resort to remain resilient and sustainable (in environmental and economic terms) in the face of environmental change. Some journalists likewise adopt this climatological narrative in describing the Snowbowl expansion; articles on the topic of Snowbowl's expansion (which has gained some degree of national and international media attention) regularly attribute the wastewater snowmaking at the resort to climate change bringing warmer, shorter, and drier winters in the Southwest (Cowan 2018; Konkel 2014; Pela 2016; Woods 2018).

This narrative of snowmaking-as-adaptation promulgated by Snowbowl, some individuals within the USFS, and various news sources, is likewise reflective of the scholarly and gray literature, which has often treated snowmaking as a (or perhaps the) climate change adaptation strategy for the ski industry (Bark and Colby 2012; Scott et al. 2008). The increased prevalence in U.S. and other resorts utilizing snowmaking has been attributed to warmer winters, decreased and unpredictable snowfall, and shorter seasons associated with climate change (Burakowski and Magnusson 2012: 3; Duquette 2016). The ski industry is widely recognized to be extremely vulnerable to climate change (Klein and Travis 2012; Scott et al. 2008: 578), especially for low-latitude ski areas such as Snowbowl (Brice et al. 2017). Indeed, Bark and Colby (2012) suggest that without snowmaking, ski resorts in Arizona as they currently exist will in fact become unfeasible under changing climatic conditions over the long term.

The snowmaking at Snowbowl, however, has an additional wrinkle. It is the first US resort to use entirely reclaimed water for its artificial snow, and resort spokespersons and others have presented the move as an environmentally progressive strategy by not over-utilizing Arizona's freshwater, particularly in light of continued climate change. Arizona Snowbowl representatives, and the USFS EIS, have presented the reclaimed wastewater as safe, legal, and "the only sustainable way of making snow" in this context (Richland 2017: 225). Jason Stratton, a Snowbowl spokesman, states "You don't take a precious resource like water in the desert and throw it on the ski hill", arguing for reclaimed water as more sustainable than other water given drought conditions in Arizona (Konkel 2014). In fact, towards the beginning of the snowmaking proposal process representatives of the resort met with local environmentalists (such as Sierra Club - Grand Canyon Chapter) and argued that snowmaking was environmentally friendly given the water source, which it framed as "recycled" water (thus tying it in with recycling generally). As we will see, this narration was rejected by many local environmentalists and indigenous people who presented an interlocking set of objections to the snowmaking as a force of desecration and disruption. In short, scholars, journalists, some individuals within the USFS, and the resort ownership itself have at times presented snowmaking as an adaptation to climate change.

\section{Snowmaking as environmental havoc}

Many residents of Flagstaff, surrounding areas, and nearby reservation communities overtly rejected the notion of snowmaking as a sustainable adaptation to the changing climate of the Southwest. Indeed, many suggest that it is the exact opposite, perpetrating environmental havoc and contributing in the process to anthropogenic climate change.

One of the most salient critiques of the snowmaking endeavor has been the sheer amount of energy required to generate the snow. At 9,200-12,000 feet [2,804-3,658 meters] above snow level (Arizona Snowbowl N.d.) the resort is several thousand feet above the water reclamation facilities, which are at 7,000 feet [2,133 meters] above sea level, and which utilize water reclaimed in the city of Flagstaff. Thus, the reclaimed water must be pumped from these facilities, through a 14.8 mile [23.8 kilometer] pipeline (USDA Forest Service 2005) and up a slope of over 2,200 feet [670.5 meters]. Additionally, the pipeline requires two booster stations to facilitate this uphill transport, and energy is additionally required for a pumphouse/compressor near the

\footnotetext{
${ }^{4}$ However, note that elsewhere resort management has denied the role of climate change in the snowmaking decision (Woods 2018).
} 
impoundment lake that the water is pumped to for snow production, for a snowmaking control building, and, most obviously, for the spraying of the snow itself via the snowmaking guns. All of this is in addition to many other energy impacts of the expansion unrelated to snowmaking (such as deforestation). Of these many energy uses, the one most frequently raised by environmentalists with whom I spoke during my time in Flagstaff was the pumping of water uphill, perhaps because of its symbolic audacity. The implication is clear: given that much of this energy will be provided by fossil fuels (US EIA 2018), in "adapting" to climate change Snowbowl is in fact exacerbating it by producing more greenhouse gases than there otherwise would be. Even if the effect for the global total is small, it nonetheless displays a sort of microcosm of the perverse resilience of the fossil fuel industry (Phelan et al. 2013) - in this case, to remain resilient, Snowbowl in fact worsens the problem. In such a narrative, Snowbowl occupies Hughes' "victim slot" wherein it positions itself as traumatized by (while directly contributing to) anthropogenic climate change (Hughes 2013).

Another predominant (and potent) theme in environmentalist stories of snowmaking is water misuse amid a changing waterscape. At a time when Arizona has been in a drought lasting since 1994 (Arizona Department of Water Resources n.d.), the City of Flagstaff allocated approximately 180 million gallons [681.4 million liters] of reclaimed water per year for snowmaking in their contract with the Arizona Snowbowl. The resort may procure up to 1.5 million gallons [5.7 million liters] per day of reclaimed water (USDA Forest Service 2005). Some residents saw this as a foolish waste of water, given the potential future need to provision this water for more urgent needs under conditions of water scarcity that they see as inevitable given both regional trends and global climate change. They are concerned that at some point reclaimed water will be needed for more essential uses than winter recreation, but that the water will have already been committed to the ski resort. As noted by one highly involved activist:

[T]he biggest part [with my opposition to snowmaking] was the water issue and just seeing it as a long-term water management issue, knowing that we're in the desert, that water in Arizona is a very insecure thing, knowing our history of constantly having to dig deeper and deeper wells...that we should not be assigning our water, whether it's processed reclaimed water or whether it's fresh water, to a recreational use long-term without knowing what our water future is going to be.

That objection only became heightened when the City committed itself to a 20-year "renewal" of its Snowbowl contract without public input or a vote in 2014, a move that was panned by local environmentalists (Arizona Daily Sun 2014).

Concerns with water (mis)management were amplified in 2010 when it was proposed that potable water be utilized for snowmaking instead of reclaimed, prompting outrage from a broad coalition of residents. Public meetings regarding the proposal drew hundreds of attendants, many of whom had no issue with snowmaking previously. As noted by one local NGO leader:

A lot of people who ski up there, who love Snowbowl, who think it's totally fine to go up there, who didn't come out for the whole reclaimed water marches and protests, suddenly came out...[b]ecause now it's water. And there were a lot of people who came up there [at the public meetings] and said "I have no problem using reclaimed water, I have no problem with Snowbowl, [but] do not use our water, you've crossed a line."

Behind these shifting valences of water usage stands the specter of drought, and thus of climate change. Actors (NGO, citizen, and corporate) struggle over limited water resources in the changing Arizona landscape. While we often think of the Anthropocene as a temporal epoch (Crutzen 2002), we might conceptualize it instead as a spatial landscape within which actors (re)position themselves across new terrain set by climatic and environmental perturbations and distortions, opportunities and constraints. 
Misuse of water and greenhouse gas production are the most clearly climate-related environmental critiques levelled at Snowbowl. However, there are many other concerns raised by locals that serve, some more obliquely than others, to directly challenge the grounds on which snowmaking can be considered adaptive to the environment. Perhaps the most salient is pollutants within reclaimed water. As noted, proponents have characterized the water as safe and uniquely environmental inasmuch as it is recycled - yet this very recycling makes it vulnerable to significant criticism. Despite having been through biotic, abiotic, and UV treatment processes, and its (oft-cited) classification as "A+" by the Arizona Department of Environmental Quality (ADEQ), there are remaining elements within the reclaimed water in question which bespeak its history of municipal usage (Hollenhorst 2013). Pruden et al. (2012) found a variety of contaminants in a sampling of the reclaimed water source used for snowmaking, including antibiotic-resistant genes. Dr. Catherine Propper found that the reclaimed water from this facility contains trace contaminants, including antibiotics, steroids, pharmaceuticals, and tobacco byproducts; Propper also noted that the water samples had caused amphibians in experiments to metamorphose unnaturally fast (Macmillan 2012; Muller 2004). More broadly, as has been noted by Propper (2005), endocrine disruptors that are found in wastewater can cause feminization of fish and amphibian populations. Another issue with the reclaimed wastewater is increased levels of phosphorous and nitrogen (as well as moisture) even beyond the ski area due to windblown snow (as documented by SWCA Environmental Consultants) (Smith 2012). The Hopi Tribe used this as the grounds for a lawsuit holding that the USFS needed to consider the impacts of such contamination on the threatened San Francisco Peaks groundsel (Packera franciscana) (Smith 2012). Activists opposed to snowmaking have regularly cited these toxicological concerns with the artificial snow, wearing hazmat suits to demonstrations, and putting hazardous waste symbolism on signs to emphasize the toxicity of snowmaking. It is "toxic desecration" in the eyes of many (Dunstan 2016).

Defenders of Snowbowl rhetorically present snowmaking with reclaimed wastewater as clean, green, and necessary in the new climate. However, opponents and concerned residents envision the water very differently, with narratives drawing on a variety of forms of data to build a convincing case that snowmaking is in fact disruptive and maladaptive to the local climate, and that it contributes further to the deterioration of the global climate. This re-framing highlights the political nature of knowledge claims regarding pollution and sustainability in regard to adaptation policy. Not only is one person's adaptation another person's vulnerability, but what "adaptation" is to begin with, is itself highly contested.

\section{Victims of "adaptation"}

Beyond concerns over water sustainability, endocrine disruptors, and greenhouse gases, lies an additional, intertwined set of concerns that, for some, constitute the defining narrative: snowmaking as desecration. Rejecting Snowbowl's self-articulation as a sustainable adapter, many indigenous voices, instead, highlighted the innate disruptiveness of the technology to (sacred) ecology.

Thirteen indigenous nations relate to the San Francisco Peaks as sacred within traditional lifeways. Several - notably the Navajo Nation, Hopi Tribe, Havasupai Tribe, the Yavapai-Apache Nation, and the White Mountain Apache Tribe - engaged in litigation to prevent snowmaking. Simultaneously, many indigenous individuals from these nations, as well in the border town of Flagstaff, organized their own separate activism at a grassroots level. The confluence of these indigenous individuals, environmental activists, and others, led to anti-snowmaking movements such as Protect the Peaks, within which Diné individuals have played a significant role. From 2009-2015, I engaged in ethnographic fieldwork with activists opposing Snowbowl's expansion; I also spent time working with the Diné Policy Institute at Diné College. In these contexts, I was able to hear a large number of indigenous people provide their own stories about snowmaking. These stories directly contravene the framing of Snowbowl as a sustainable adaptation. My focus herein will be specifically on Diné voices (among the many indigenous peoples opposed), as these are the individuals and groups with whom I had the most direct experience during fieldwork.

Diné associates largely expressed vehement opposition to snowmaking, seeing it as innately disruptive to the environment, in many ways mirroring and contributing to the rhetorical opposition already discussed. Yet 
this ecological disruptiveness was narrated in relation to a paradigm of environmental change which emphasized the morality and rationality of actors in assessing the desirability of change. Interviews reflected what court cases and environmental impact assessments had already borne witness to, that snowmaking was opposed by many Diné on the grounds of the intrinsic, central sacredness of the mountain, and the holy relationships it holds with Diné people. Interestingly, however, there were several arguments used to explain why artificial snowmaking constituted desecration (Dunstan 2016), including its chemical constituents, ritual impurities, and basic disrespectfulness due to scatological connotations (i.e. "It's like pissing on a church"). Most importantly for this climatological discussion, however, is that snowmaking was seen as an unwise and presumptuous attempt to control weather that would inevitably lead to disaster; "with anything manmade there is going to be danger", as an interviewee from Leupp, AZ, expressed it.

Diné people with whom I spoke presented snowmaking not as an adaptation to climate change, but rather as an obstinate refusal to adapt to changes in the weather. During one of my first interviews in 2009, I asked a Diné man (who happened to be the son of a hatati ${ }^{5}$ and a cultural expert in his own right) why Diné people opposed snowmaking; he initially responded quite straight-forwardly: "It's artificial." He later expounded:

One thing about how a Navajo sees the mountains, as well as the earth, the water, the air, and the sunlight/fire, the four elements - we do not make rules for them...Y You cannot make a rule for the water. The water has its own things: you just have to follow it.

In this same vein he later remarked, "We just have to follow the natural order... Why do you have to have snow year round?...It will come again." Part of the rules for water, then, is the natural patterns of snowfall, and snowmaking is a dangerous attempt to change this order - and, more fundamentally, to redirect the natural progression of the environment. This basic concept became reiterated in nearly every interview which involved Diné individuals. Statements such as "Just let it snow", "It's okay, as long as it's natural", and (again) "With anything manmade there is going to be danger" peppered my interviews. Such statements resonate with important principles in traditional Diné thought. ${ }^{6}$ For example, the Navajo Nation Fundamental Laws of the Diné (a codification of key elements of Diné knowledge within Navajo Nation law) states that "The four sacred elements of life, air, light/fire, water and earth/pollen in all their forms must be respected, honored, and protected for they sustain life... Mother Earth and Father Sky is part of us as the Diné and the Diné is part of Mother Earth and Father Sky; the Diné must treat this sacred bond with love and respect without exerting dominance for we do not own our mother or father" (Navajo Nation Council 2002, emphasis added). As one Diné man explained to me regarding the Fundamental Laws, "Natural law at creation time established that no one life being was put in a place of controlling: no dominating."

The implicit climatological logic of this discourse is that seasons are to be followed, rather than controlled - that to control is both disrespectful and likely to have extremely negative consequences. One might go so far as to say that the natural shift of the seasons is indicative of a morally proper climate. Such a paradigm is productive in considering snowmaking-as-adaptation. From this perspective, snowmaking can be seen as an attempt not so much to adapt to change (as its proponents argue) as to arrest change - to fix the climate at a desired point, and in so doing to defy sacred natural law. Snowmaking changes climate too - but in a direction contrary to the original patterns of continual change, thus being morally devalued (for this among many other reasons). Furthermore, it was regularly emphasized that this artifice was engaged in for human convenience and greed for the "almighty dollar." Thus, change was not so much the central issue as who drove the change, in what ways, for what ends, and in what direction - a climatological narrative implicitly moral and relational.

\footnotetext{
${ }^{5}$ Often glossed in English as "medicine person", "medicine man", "singer", and "healer" (Lee 2014).

${ }^{6}$ I realize that "traditional Diné thought" here is a potentially arbitrary and contestable term (in the light of what counts as "traditional"). Here I am using the term to refer to those discourses, ceremonies, and knowledge understood as having been transmitted from time immemorial, and thus pre-existing the spread of Christianity into Diné society. "Traditionalism" is, in this sense, highly diverse. I discuss some of the complexities of this term (and my reasons for nonetheless using it) in Dunstan (2016).
} 
Finally, this calls to mind Crate's statement that "In the field, we need to understand how our research partners frame the local effects of global climate change in order to tease out the cultural implications" (2008: 575).

Beyond this moral climatology, climate change kept appearing in other small ways in conversations with Diné people about snowmaking during research, despite my lack of attempts to evoke the topic. It seemed to have left tidemarks in the discourses of activism which one was bound to run into should you traverse the conversational beaches long enough. In 2010, I participated in the final leg of a lengthy walk by a Diné farmer from the interior of the reservation to Flagstaff (a distance of several hundred miles). The purpose of the walk was to generate publicity about the ongoing crisis of snowmaking and other environmental issues facing the Navajo Nation. While we walked, he received a scheduled phone call with the popular radio program Native America Calling. As he spoke, he described the holy mountain as "The San Francisco Peaks, in Navajo they are called Dook'o'oostiild, which means 'always snowy on top', but now it's a different time, with climate change." This calls to mind Basso's prescient observation that indigenous place-names can serve as indices of environmental change across time (Basso 1997).

While anti-snowmaking was rarely overtly framed as a climate justice issue in the way, for example, oil extraction has been at times within the \#NoDAPL movement, climate seemed to be part of the gestalt of opposition to Snowbowl. For example, the Protect the Peaks Facebook page posted that "In the face of climate change...we stand today to defend the lands held holy by Indigenous Peoples." Ecocide, climate change, and snowmaking were treated as implicitly linked and occupying the same oppositional space in Protect the Peaks narratives of snowmaking.

With this in mind, we might think of anti-snowmaking activism as being, among many other things, a form of climate change activism, to which indigenous peoples are arguably central (Crate 2008: 571). Yet it is a climate change activism of an unexpected sort for it is not so much against climate change directly, as contrary to the monsters spawned indirectly by climate change - desecration as corporate entities attempt to maintain a false sustainability in the Anthropocene.

\section{Conclusion}

The further back one stands from a piece of basketry, the more certain patterns become clear; so it is with my research into grassroots opposition to the expansion of Arizona Snowbowl. With increasing reflection, it becomes apparent that climate change runs as a thread through the entire snowmaking/desecration/opposition phenomena. Although hardly the dominant theme, if climate change were removed from the story, the battle over snowmaking at Snowbowl would appear to be entirely different. ${ }^{7}$ Presented implicitly by proponents as a form of resiliency, many saw Snowbowl's expansion as indicative of, and indeed producing, climate chaos. While resort owners emphasized snowmaking as an environmentally benign adaptation, many local people told a different story, where Snowbowl was a driver rather than a victim of climate chaos, producing greenhouse gases, hoarding water, and spewing toxins. Diné individuals also particularly emphasized snowmaking's failure to adapt, framing it in the moral terms of traditional Diné thought as an avaricious attempt to fix ever-changing weather. The attempt at Snowbowl greenwashing - and the environmentalist and indigenous inimical response - speaks to a fundamental tension in climate change thinking. The framing of snowmaking-as-adaptation to climate change (and its facilitation by both local and federal governmental bodies) raises significant questions about the resiliency regime in policy and scholarship, namely, which institutions we should invest in while adapting to climate change.

One question that emerges in this study, and in many others, is the ways in which the frameworks of sustainability, adaptation, and resilience can be used to harm communities, despite their popularity in environmental policy and scholarship. We should attend to those vulnerable to perverse adaptations where

\footnotetext{
${ }^{7}$ This certainly is not limited to my own fieldwork. Climate change is so all-encompassing that to study contemporary water management or public land use or sacred sites is, implicitly, to study climate change. I would argue that for those of us interested in battles over indigenous sacred lands, we must consider how climate change will transform, and in many cases accelerate, the conditions under which these battles are waged.
} 
certain actors and institutions (such as ski resorts) are maintained at the expense of others (such as indigenous traditionalists or municipal water users). The framework of adaptation and resiliency - while fundamentally essential to survival in a changing world - nonetheless can be co-opted by the economically powerful to justify drastic infrastructural measures to "sustain" (and even improve) the continued profit of business interests. Adaptation policies often require significant investments of ecological and economic capital. For Snowbowl's adaptation, this capital includes millions of gallons of water, federal land usage for the water pipeline and resort expansion, and energy for operations, all dedicated to a for-profit business operating on federal land and opposed by many local groups and indigenous nations. ${ }^{8}$ This costly adaptation highlights what is likely a more widespread trend in the usage of resiliency discourse, wherein industrial societies and actors attempt to adapt to a changed climate by utilizing ever more desperate technologies (such as weather modification) to maintain and enhance the economic status quo. In such contexts, we must ask about the "limits of adaptation" (Adger $e t$ al. 2009) - whether all businesses, all activities, should even be "sustained" or "adapted", and what the costs will be if we try to do so. Does the concept of resiliency accommodate adapting to a reduced scale of human activities, or does resiliency mean attempting to force the square peg of our current political economy into the round hole of the Anthropocene?

Like many other environmental terms, then, "resiliency" and "adaptation" must be considered carefully in terms of their actual manifestations and implications. As noted by Anderson in regard to another popular environmental policy word, "Sustainability is an idea laden with contradictions, which leaves it wide open for political and social manipulation" and "seems malleable enough to mean just about anything" (Anderson 2015: 240, 251). Have "resiliency" and "adaptation" become just as malleable and, if so, how might we realign these important, necessary concepts so they can be useful for justice and survival in our times of ecological crisis? To do so we must attend to the politics behind this seemingly objective scientific terminology.

In this case, Snowbowl, activists, and others engaged in a discursive war over proper "adaptation" to climate change, while both sides fought to define climate victims and perpetrators. Such cases prompt the question: must all institutions become adapted to climate change, or should we allow some to not be resilient to fail? As McDonald (2017) remarks, "The challenge, therefore, is to identify approaches and goals that move beyond preservation or restoration of the status quo, since maintenance of the status quo is simply unfeasible...Governance arrangements will have to be premised on dynamism, rather than a stable set of baseline conditions", (p. 32). Similarly, Hirsch (2017) states, "defining the unit of resilience is a political act, for it is a means of prioritizing what, in a human-driven ecosystem, should remain permanent" (p. 464).

The narrative that emerges from those who oppose snowmaking is that snowmaking is not resiliency in its fullest sense, but corporate capitalism being maintained in the face of drought at great expense to other people, other publics, and other victims. The use of recreational technology (such as snowmaking) with significant ecological impact is symptomatic of late capitalism more broadly (Crate 2008: 570), with corporate interests both driving and seeking to be protected from climate change, while drawing down or impacting public resources. One of the arguments for this public involvement in private business is the necessity to keep Snowbowl operating given its (disputed) contribution to the local economy; this calls to mind Igoe and Brockington's critique of neoliberal conservation (Igoe and Brockington 2007) and the basic contradiction inherent in seeking to simultaneously protect all business and all environmental concerns amidst environmental shifts.

The Chimerical dream of using artificial snowmaking technology to arrest changing climatic conditions is well-exemplified by activists' posting of pictures of a sunny day in 2017 when there was a single patch of artificial snow surrounded by otherwise sunny and temperate conditions - an entirely human-made snowfall. Such images remind us that snowmaking not only contributes to climate change, it is climate change - if we consider the micro-climate of a mountain slope. After all, to attempt to make snow is to wrest climatic control, at least temporarily, in a contingent manner. Ironically in such cases resistance to climate change is, itself,

\footnotetext{
${ }^{8}$ Additionally, the City of Flagstaff sells the wastewater utilized by Snowbowl for snowmaking at a lower price than the treatment cost; some see this as a taxpayer subsidy to the corporation, although an argument voiced by some members of the City government is that this is a means to partially recoup some of the investment in reclaiming water.
} 
changing the climate. One might ask then whether hegemonic forces within government and industry truly oppose climatic change, or simply certain forms of it. After all, emitting greenhouse gases from a smokestack and ejecting snow from a cannon both change the weather (albeit at entirely different scales).

It is significant that, a decade after Crate's (2008: 570) commentary on the relative lateness and paucity of climate scholarship in anthropology (a disciplinary perspective from which I write), there is a very robust body of ethnographic work on the local impacts of climate change. I would argue that, for those of us conducting research on climate change from an ethnographic perspective, one means by which we can engage with global climate change is by additionally pursuing paths outside well-worn trails of climate change discourse. By "wellworn trails", I mean documenting impacts, vulnerabilities, and resistances that we are already familiar with in academic and popular representation, such as sea level rise, climate refugees in coastal communities, and increased catastrophic storms. While all are critically important, we must also consider more unexpected victims - victims, in this case, of adaptation, and of the political contingencies of climate change. We must interrogate not only climate change's primary effects but also its indirect aftershocks, as phenomena such as droughts produce new conditions in which other disruptive regimes - such as snowmaking - take hold and spawn their own host of impacts, including additional sacred land desecration.

Yet if the co-opting of resiliency policy calls into question concepts and terms we might assume to be environmentally progressive and benign, then the opposition by activists and intellectuals cited here must cause us to remember that there are alternative politics and framings for climate change. There is more than one way to "story climate change" (Crate 2017), its unexpected victims, aftershocks, and perverse causes.

\section{References}

Adger, W.N., T.P. Hughes, C. Folke, S.R. Carpenter and J. Rockström. 2005. Social-ecological resilience to coastal disasters. Science 309(5737): 1036-1039.

Adger, W.N., S. Dessai, M. Goulden, M. Hulme, I. Lorenzoni, D.R. Nelson, L.O. Naess, J. Wolf and A. Wreford. 2009. Are there social limits to adaptation to climate change? Climatic Change 93(3/4): 335354.

Anderson, R.B. 2015. Sustainability, ideology, and the politics of development in Cabo Pulmo, Baja California Sur, Mexico. Journal of Political Ecology 22: 239-254.

Arizona Daily Sun. 2014. City of Flagstaff approves Snowbowl snowmaking contract for 20 years. [accessed January 16, 2019]. Arizona Daily Sun Aug. 9. https://azdailysun.com/news/local/city-of-flagstaffapproves-snowbowl-snowmaking-contract-for-more-years/article_9a89939e-1f90-11e4-84e2001a4bcf887a.html.

Arizona Department of Water Resources. N.d. Drought frequently asked questions. [accessed January 16, 2019]. https://new.azwater.gov/drought/faq.

Arizona Snowbowl. N.d. Mountain information. [accessed January 16, 2019]. https://www.snowbowl.ski/themountain/mountain-information/.

Bark, R.H. and B.G. Colby. 2012. Climate, changing snowpack, and the future of winter recreation. In B.G. Colby and G.B. Frisvold (eds.). Adaptation and resilience: the economics of climate, water, and energy challenges in the American Southwest. Washington D.C.: Earthscan. Pp. 145-162.

Basso, K. 1996. Wisdom sits in places: landscape and language among the Western Apache. Albuquerque: University of New Mexico Press.

Bodley, J.H. 1975. Victims of progress. San Francisco: Cummings Publishing Company.

Boggs, K. 2017. The material-discursive spaces of outdoor recreation: rhetorical exclusion and settler colonialism at the Arizona Snowbowl Ski Resort. Journal for the Study of Religion, Nature, and Culture 11(2): 175-196.

Brice, B., C. Fullerton, K.L. Hawkes, M. Mills-Novoa, B.F. O'Neill and W.M. Pawlowski. 2017. The impacts of climate change on natural areas recreation: a multi-region snapshot and agency comparison. Natural Areas Journal 31(1): 86-97. 
Burakowski, E. and M. Magnusson. 2012. Climate impacts on the winter tourism economy in the United States. National Resources Defense Council. [accessed January 16, 2019]. https://www.nrdc.org/sites/default/files/climate-impacts-winter-tourism-report.pdf.

Cannon, T. and D. Müller-Mahn. 2010. Vulnerability, resilience and development discourses in context of climate change. Natural Hazards 55: 621-635.

Chiang, F., O. Mazdiyasni and A. AghaKouchak. 2018. Amplified warming of droughts in southern United States in observations and model simulations. Science Advances 4(8): eeat2380.

Collins, T.W. 2008. The political ecology of hazard vulnerability: marginalization, facilitation and the production of differential risk to urban wildfires in Arizona's White Mountains. Journal of Political Ecology 15: 21-43.

Cowan, E. 2018. US tribe fights use of treated sewage to make snow on holy peaks. The Guardian 15 Feb. [accessed January 16, 2019]. https://www.theguardian.com/environment/2018/feb/15/arizona-snow-skihopi-tribe-lawsuit.

Crate, S. 2008. Gone the bull of winter? Grappling with the cultural implications of and anthropology's role(s) in global climate change. Current Anthropology 49(4): 569-595.

Crate, S. 2017. Storying climate change. Anthropology News 58(2): e64-e69.

Crutzen, P. 2002. Geology of mankind. Nature 415: 23.

Dunstan, A.D. 2010. "With anything manmade there is going to be danger": the cultural context of Navajo opinions regarding snowmaking on the San Francisco Peaks. Indigenous Policy Journal 21(2):1-6.

Dunstan, A.D. 2016. Toxic desecration: science and the sacred in Navajo environmentalism. Ph.D. dissertation. Buffalo: University at Buffalo.

Dunstan, A.D. 2017. Legislative ambiguity and ontological hierarchy in US sacred land law. American Indian Culture and Research Journal 41(4): 23-43.

Duquette, K.A. 2016. Don't eat the brown snow! Utilizing wastewater for artificial snow: A slippery slope between protecting skiers and encouraging water reuse. Villanova University Environmental Law Journal 27(1): 124-148.

European Commission. N.d. EU Adaptation strategy. [accessed January 14, 2019]. https://ec.europa.eu/clima/policies/adaptation/what_en.

Fischer, H. 2018. State justices end tribal dispute with ski area. Arizona Capitol Times Nov. 28. [accessed January 21, 2019]. https://azcapitoltimes.com/news/2018/11/29/state-justices-end-tribal-dispute-withski-area/.

Glowacka, M., D. Washburn and J. Richland. 2013. Nuvatukya'ovi, San Francisco Peaks: balancing Western economies with Native American spiritualties. Current Anthropology 50(4): 547-561.

Hirsch, E. 2017. The unit of resilience: unbeckoned degrowth and the politics of (post)development in Peru and the Maldives. Journal of Political Ecology 24(1): 462-475.

Hollenhorst, J. 2013. Treated sewage water used on the ski slopes in Arizona: is this a sign of things to come in Utah? Deseret News [accessed January 16, 2019]. https://www.deseretnews.com/article/865576636/Treated-sewer-water-used-on-the-ski-slopes-inArizona.html.

Holling, C.S. 1973. Resilience and stability of ecological systems. Annual Review of Ecology and Systematics 4: $1-23$.

Hughes, D.M. 2013. Climate change and the victim slot: from oil to innocence. American Anthropologist 115(4): 570-581.

Igoe, J. and D. Brockington. 2007. Neoliberal conservation: a brief introduction. Conservation and Society 5(4): 432-449.

Intergovernmental Panel on Climate Change (IPCC). 2019. Special report: global warming of $1.5^{\circ} \mathrm{C}$ : Glossary. Geneva: IPCC. [accessed July 11, 2019] https://www.ipcc.ch/sr15/. 
Klein, R.A. and W.R. Travis. 2012. Socioeconomic impacts and adaptation strategies: assessing research on drought, climate change, and recreation. Western Water Assessment White Paper. Boulder: Western Water Assessment.

Kokorsch, M. 2018. Mapping resilience - coastal communities in Iceland. Ph.D. dissertation. Reykjavík: University of Iceland.

Konkel, L. 2014. Snowmakers save ski season in warming world, for now. Climate Central [accessed January 16, 2019]. https://www.climatecentral.org/news/snowmakers-save-ski-season-in-warming-world-fornow-17045.

Lagasse, B.R. 2008. Waiting for the snow to fall: First Nations, federal policy, and environmental justice. MS Thesis. Arcata: Humboldt State University.

Lazrus, H. 2012. Sea change: island communities and climate change. Annual Review of Anthropology 41: 285301.

Lee, L. 2014. Introduction. In L.L. Lee (ed). Diné perspectives: revitalizing and reclaiming Navajo thought. Tucson: University of Arizona Press.

Leichenko, R. 2011. Climate change and urban resilience. Current Opinion in Environmental Sustainability 3(3): 164-168.

Long, B. 2017. The future of snow. Ski [accessed January 16, 2019]. https://www.skimag.com/ski-resortlife/the-future-of-snow.

Macmillan, L. 2012. Resort's snow won't be pure this year; it'll be sewage]. The New York Times [accessed January 16, 2019]. https://www.nytimes.com/2012/09/27/us/arizona-ski-resorts-sewage-plan-createsuproar.html.

Macmillan, L. 2014. Hopi lawsuit against wastewater snowmaking gets green light in Arizona. High Country News Jan. 16. [accessed January 16, 2019]. https://www.hcn.org/blogs/goat/hopi-lawsuit-againstarizona-snowbowl-wastewater-snow-proceeds.

Massey, E., R.. Biesbroek, D. Hueitema and A. Jordan. 2014. Climate policy innovation: the adoption and diffusion of adaptation policies across Europe. Global Environmental Change 29: 434-443.

McDonald, J. 2017. Risk, resilience, and environmental regulation: using law to build resilience to climate change impacts. In B.M. Hutter (ed.). Risk, resilience, inequality, and environmental law. Cheltenham: Edward Elgar. Pp. 29-48.

McPherson, R.S. 2012. Dinéjí Na 'Nitin: Navajo traditional teachings and history. Boulder: University Press of Colorado.

Muller, S. 2004. Contaminants dog city's recycled water. Arizona Daily Sun Mar. 25. [accessed January 16, 2019]. https://azdailysun.com/contaminants-dog-city-s-recycled-water/article_a53bda53-1369-5d4bbf1f-cbce10164267.html.

Nadasdy, P. 2007. Adaptive co-management and the gospel of resilience. In D. Armitage, F. Berkes and N. Doubleday (eds.). Adaptive co-management: collaboration, learning, and multi-level governance. Vancouver: University of British Columbia Press. Pp. 208-227.

Navajo Nation Council. 2002. Diné Bi Beenahaz'áanii 1. N.N.C. §§ 201-206. [accessed January 16, 2019]. http://www.navajocourts.org/dine.htm.

Nelson, D.R., C.T. West and T.J. Finan. 2009. Introduction to "In focus: global climate change and adaptation in local places." American Anthropologist 111(3): 271-274.

Newman, P., T. Beatley and H. Boyer. 2009. Resilient cities: responding to peak oil and climate change. Washington, D.C.: Island Press.

Olsson, L., A. Jerneck, H. Thoren, J. Persson and D. O'Byrne. 2015. Why resiliency is unappealing to social science: theoretical and empirical investigations of the scientific use of resilience. Science Advances 1(4): e1400217. $\quad$ [accessed January $16, \quad 2019]$. http://advances.sciencemag.org/content/advances/1/4/e1400217.full.pdf. 
Propper, C.A. 2005. The study of endocrine-disrupting compounds: past approaches and new directions. Integrative and Comparative Biology 45(1): 194-200.

Richland, J. 2017. Paths in the wilderness? The politics and practices of Hopi religious freedom in Hopitutskwa. Maryland Journal of Environmental Law 31(1): 217-243.

Pela, R.L. 2016. How Arizona Snowbowl fakes flakes for a longer season. Phoenix New Times Feb. 2. [accessed January 16, 2019]. https://www.phoenixnewtimes.com/arts/how-arizona-snowbowl-fakes-flakes-for-alonger-ski-season-8018927.

Phelan, L., A. Henderson-Sellers and R. Taplin. 2013. The political economy of addressing the climate crisis in the Earth system: undermining perverse resilience. New Political Economy 18(2): 198-226.

Pielke, R., G. Prins, S. Rayner and D. Sarewitz. 2007. Lifting the taboo on adaptation. Nature 445: 597-598.

Powell, D.E. and A. Curley. 2008. K'e, Hozhó, and non-governmental politics on the Navajo Nation: ontologies of difference manifest in environmental activism. Anthropological Quarterly 81: 17-58.

Pruden, A., M. O'Brien, M. Mazzochette and N. Fahrenfeld. 2012. Antibiotic resistance gene testing of recycled water samples. Summary report to Dr. Robin Silver. [accessed January 03, 2015].

Roncoli, C. 2006. Ethnographic and participatory approaches to research on farmers' responses to climate predictions. Climate Research 33: 81-99.

Schlosberg, D. and D. Carruthers. 2010. Indigenous struggles, environmental justice, and community capabilities. Global Environmental Politics 10(4): 12-35.

Scott, D., J. Dawson and B. Jones. 2009. Climate change vulnerability of the US Northeast winter recreation tourism sector. Mitigation and Adaptation Strategies for Global Change 13(5/6): 577-596.

Sefiha, O. and P. Lauderdale. 2008. Sacred mountains and profane dollars: discourses about snowmaking on the San Francisco Peaks. Social and Legal Studies 17(4): 491-511.

Smith, N.L. Hopi continues to fight Snowbowl. Navajo Times Nov. 21 [accessed January 16, 2019]. http://navajotimes.com/news/2012/1112/112112sno.php.

Thorén, H. and L. Olsson. 2018. Is resilience a normative concept? Resilience 6(2):112-128.

Tschakert, P. and K.A. Dietrich. 2010. Anticipatory learning for climate change adaptation and resilience. Ecology and Society 15(2): $11 \quad$ [accessed January 16, 2019 ]. https://www.ecologyandsociety.org/vol15/iss2/art11/main.html.

Tsosie, R. 2006. Challenges to sacred site protection. Denver University Law Review 83(4): 963-980.

U.S. Department of State. 2016. Second biennial report of the United States of America under the United Nations Framework Convention on Climate Change. [accessed January 14, 2019 ]. https://unfccc.int/files/national_reports/biennial_reports_and_iar/submitted_biennial_reports/applicatio n/pdf/2016_second_biennial_report_of_the_united_states_.pdf.

U.S.D.A. Forest Service. 2005. Final Environmental Impact Statement for Arizona Snowbowl facilities improvements, $\quad$ Volume $\quad 1 . \quad$ [accessed $\quad$ January $\quad 16, \quad 2019]$. https://www.fs.usda.gov/Internet/FSE_DOCUMENTS/stelprd3831728.pdf.

U.S. Environmental Protection Agency. 2012. 2012 Guidelines for water reuse. Washington, D.C.: U.S. Environmental Protection Agency.

Woods, A. 2018. Winter helps give Flagstaff an identity. What happens when it's not so wintry? Arizona Central Dec. 14. [accessed January 14, 2019]. https://www.azcentral.com/story/news/local/arizonaenvironment/2018/12/14/climate-change-flagstaff-winter-identity-snowbowl-ski-shops-humphreyspeak/2198753002/. 